\title{
Back-Contacted Silicon Heterojunction Solar Cells: Optical-Loss Analysis and Mitigation
}

\author{
Bertrand Paviet-Salomon, Andrea Tomasi, Antoine Descoeudres, Loris Barraud, Sylvain Nicolay, \\ Matthieu Despeisse, Stefaan De Wolf, and Christophe Ballif
}

\begin{abstract}
We analyze the optical losses that occur in interdigitated back-contacted amorphous/crystalline silicon heterojunction solar cells. We show that in our devices, the main loss mechanisms are similar to those of two-side contacted heterojunction solar cells. These include reflection and escape-light losses, as well as parasitic absorption in the front passivation layers and rear contact stacks. We then provide practical guidelines to mitigate such reflection and parasitic absorption losses at the front side of our solar cells, aiming at increasing the short-circuit current density in actual devices. Applying these rules, we processed a back-contacted silicon heterojunction solar cell featuring a short-circuit current density of $40.9 \mathrm{~mA} / \mathrm{cm}^{2}$ and a conversion efficiency of $22.0 \%$. Finally, we show that further progress will require addressing the optical losses occurring at the rear electrodes of the back-contacted devices.
\end{abstract}

Index Terms-Heterojunction, interdigitated back-contact, optical losses, parasitic absorption, silicon, solar cell.

\section{INTRODUCTION}

A MORPHOUS/CRYSTALLINE silicon heterojunction (SHJ) solar cells are promising candidates to achieve high conversion efficiencies at competitive cost [1]. Owing to the outstanding passivation level of the crystalline silicon (c-Si) surface obtained by hydrogenated amorphous silicon (a-Si:H) layers, two-side contacted SHJ solar cells feature to date opencircuit voltages $\left(V_{\text {oc }}\right)$ as high as $750 \mathrm{mV}$ and efficiencies up to 24.7\%, as demonstrated by Panasonic, Japan [2].

However, two-side contacted SHJ architectures, with the hole collector ( "emitter," for n-type wafers) either located at the front (FE-SHJ) or at the rear (RE-SHJ) of the devices, are ultimately limited by front metal grid shadowing and parasitic absorption

Manuscript received March 12, 2015; revised May 8, 2015; accepted May 22, 2015. Date of publication July 6, 2015; date of current version August 18, 2015. This work was supported by the Swiss Commission for Technology and Innovation under Grant 13348.1, by the Axpo Naturstrom Fonds, by the European Commission (FP7 Projects HERCULES under Grant 608498 and CHEETAH under Grant 609788), by the Swiss Federal Office of Energy, by the EuroTech University Alliance in the framework of the Interface Science for Photovoltaics Initiative, by the Swiss National Science Foundation R'Equip Program under Grant 206021_139135 and Grant 206021_133832, and by Meyer Burger Research. (Corresponding author: Bertrand Paviet-Salomon, e-mail: bertrand.paviet-salomon@csem.ch)

B. Paviet-Salomon, A. Descoeudres, L. Barraud, S. Nicolay, and M. Despeisse are with the PV-Center, Centre Suisse d'Électronique et de Microtechnique, Neuchâtel CH-2002, Switzerland (e-mail: bertrand.paviet-salomon@csem. ch; antoine.descoeudres@csem.ch; loris.barraud@csem.ch; sylvain.nicolay@ csem.ch; matthieu.despeisse@csem.ch).

A. Tomasi, S. De Wolf, and C. Ballif are with the Thin-Film Electronics Laboratory, Institute of Microengineering (IMT), École Polytechnique Fédérale de Lausanne, Neuchâtel CH-2000, Switzerland (e-mail: andrea.tomasi@epfl.ch; stefaan.dewolf@epfl.ch; christophe.ballif@epfl.ch).

Color versions of one or more of the figures in this paper are available online at http://ieeexplore.ieee.org.

Digital Object Identifier 10.1109/JPHOTOV.2015.2438641 of light in the thin a-Si:H and transparent conductive oxide (TCO) deposited films [3], [4]. Meticulous efforts have been dedicated over the last few years toward the reduction of these parasitic losses, especially by thinning as much as possible the front a-Si:H layers [5] and reducing the metal-finger width using increasingly sophisticated metallization techniques [6]-[8]. To date, the best outcome for this approach is a short-circuit current density $\left(J_{\mathrm{sc}}\right)$ value of $40.0 \mathrm{~mA} / \mathrm{cm}^{2}$, obtained by Kaneka, Japan, for an SHJ solar cell with copper-electroplated contacts [6]. Other approaches include the use of window layers consisting of wider bandgap materials [9] or metal oxides [10].

Alternatively, parasitic losses can be drastically reduced by adoption of the back-contacted device architecture. In backcontacted SHJ solar cells, the hole and electron collectors, and their respective electrodes, are placed at the rear side of the device [11]. The front side is, hence, devoid of any front metal shadowing, increasing also the device "aesthetics." In addition, since in this design, no carrier collection occurs in the frontside layers, any related material property constraint is absent. As a result, in back-contacted devices, front-side layers can be purposely tuned to harvest efficiently sunlight. Back-contacted SHJ solar cells are thus expected to yield higher $J_{\mathrm{sc}}$ values, while still featuring the high $V_{\text {oc }}$ and implied fill-factor values characteristic for their two-side contacted counterparts. These expectations were convincingly fulfilled by Panasonic, Japan, reporting in early 2014 on a $25.6 \%$-efficient back-contacted SHJ solar cell on a full 5-in wafer [12]. This remarkable result sets a new world-record efficiency for single-junction c-Si-based solar cells under 1-sun illumination.

Table I summarizes the current state of the art of backcontacted SHJ solar cells. We limit this overview to devices with efficiency higher than $19.0 \%$ and sorted them by decreasing $J_{\mathrm{sc}}$ values. Surprisingly, most of these devices feature $J_{\mathrm{sc}}$ values lower than Kaneka's "standard" SHJ solar cell mentioned above [6]. The two notable exceptions are the results by Panasonic, Japan [12] and Sharp, Japan [13], who demonstrated $J_{\mathrm{sc}}$ values of 41.8 and $41.7 \mathrm{~mA} / \mathrm{cm}^{2}$, respectively. Noteworthy, the details on the front stack they used to reach such impressive $J_{\mathrm{sc}}$ values remain not completely disclosed so far. From these results, we infer that proper optimization of sunlight absorption and carrier collection in back-contacted SHJ solar cells may not be so straightforward. Indeed, the front-side layers of such devices must provide simultaneously sufficiently high electrical passivation and optical transparency, while also featuring a suitable refractive index for antireflection coating (ARC) purposes.

Several reasons may be held accountable for the peculiar fact that most back-contacted SHJ devices have yet to achieve 
TABLE I

STATE-OF-THE-ART OF BACK-CONTACTED SHJ SOLAR CELLS WitH EFFICIENCY HIGHER THAN $19.0 \%$, SORTED BY DECREASING $J_{\text {Sc }}$

\begin{tabular}{lcccccc}
\hline \hline $\begin{array}{l}\text { Affiliation and } \\
\text { reference }\end{array}$ & Year & $\begin{array}{c}\text { Area } \\
{\left[\mathrm{cm}^{2}\right]}\end{array}$ & $\begin{array}{c}J_{\mathrm{sc}} \\
{\left[\mathrm{mA} / \mathrm{cm}^{2}\right]}\end{array}$ & $\begin{array}{c}V_{\text {oc }} \\
{[\mathrm{mV}]}\end{array}$ & $\begin{array}{c}\mathrm{FF} \\
{[\%]}\end{array}$ & $\begin{array}{l}\text { Eff. } \\
{[\%]}\end{array}$ \\
\hline $\begin{array}{l}\text { Panasonic, } \\
\text { Japan [12] }\end{array}$ & 2014 & $143.7(\mathrm{da})$ & 41.8 & 740 & 82.7 & 25.6 \\
$\begin{array}{l}\text { Sharp, } \\
\text { Japan [13] }\end{array}$ & 2014 & $3.72(\mathrm{ap})$ & 41.7 & 736 & 81.9 & 25.1 \\
$\begin{array}{l}\text { CSEM-EPFL } \\
\text { this work) }\end{array}$ & 2015 & $9.0(\mathrm{da})$ & 40.9 & 726 & 74.0 & 22.0 \\
$\begin{array}{l}\text { EPFL, } \\
\text { Switzerland [14] }\end{array}$ & 2014 & $9.0(\mathrm{da})$ & 39.9 & 724 & 74.5 & 21.5 \\
$\begin{array}{l}\text { HZB-ISFH, } \\
\text { Germany [15] }\end{array}$ & 2011 & 1 (da) & 39.7 & 673 & 75.7 & 20.2 \\
$\begin{array}{l}\text { CEA-INES, } \\
\text { France [16] }\end{array}$ & 2014 & $18.1(\mathrm{da})$ & 38.6 & 689 & 74.9 & 19.9 \\
$\begin{array}{l}\text { LG, } \\
\text { Korea [17] }\end{array}$ & 2014 & 221 (ta) & 37.5 & 716 & 76.4 & 20.5 \\
\hline \hline
\end{tabular}

ap: aperture area; da: designated area; ta: total area (see [18]). FF: fill-factor. Eff.: conversion efficiency.

top $J_{\mathrm{sc}}$ values. First and foremost, two front-side schemes are predominantly featured in such devices: either a-Si:H layers combined with dielectrics-based ARCs [14], [17], [19]-[22] or high-temperature diffused front-surface fields (FSF) combined with ARCs [15], [23]. These two options originate from stacks standardly used in two-side contacted solar cells, usually featured at the front side of both heterojunction [24] and homojunction [25] rear-emitter devices, respectively.

Some alternatives to these front stacks have also been investigated. The zinc sulfide/silicon carbide stack proposed by Shu et al. [22] yielded a $J_{\mathrm{sc}}$ of $31.2 \mathrm{~mA} / \mathrm{cm}^{2}$ : a value mainly limited due to a low passivation level. Similarly, the native oxide/silicon nitride scheme introduced by Chowdhury et al. [26] led to a maximum $J_{\mathrm{sc}}$ of $35.4 \mathrm{~mA} / \mathrm{cm}^{2}$ [27]. Doubtlessly, these values are also seriously limited, since for both results, mirror-polished wafers were used. Ziegler et al. [28] processed back-contacted SHJ devices with black silicon at the front, aiming at enhanced light absorption. However, this approach has yet to lead to higher $J_{\mathrm{sc}}$ values than those achieved with a standard pyramid-textured front side using a potassium hydroxide solution.

For homojunction back-contacted devices, Ohrdes et al. [29] recently showed that the diffused FSF is mainly required to maintain high passivation at low injection levels at the front side, rather than to provide additional lateral conductivity for majority carriers. Hence, the FSF can advantageously be replaced by a dielectric layer with a high fixed charges density, such as aluminum oxide [29]. Along these lines, using an aluminum oxide/silicon nitride stack to passivate the undiffused front side of homojunction back-contacted solar cells, Peibst et al. demonstrated a $J_{\mathrm{sc}}$ of $41.8 \mathrm{~mA} / \mathrm{cm}^{2}$ [30]. Using only silicon nitride, $J_{\text {sc }}$ values $>41.0 \mathrm{~mA} / \mathrm{cm}^{2}$ have also been reached [31]. Although originally designed for homojunction back-contacted solar cells, such front-side schemes can equally well be applied to heterojunction back-contacted devices.

Other phenomena intrinsically linked to the back-contacted SHJ architecture can also hinder the achievement of high $J_{\mathrm{sc}}$ values. Minority carriers generated above the electron-collecting

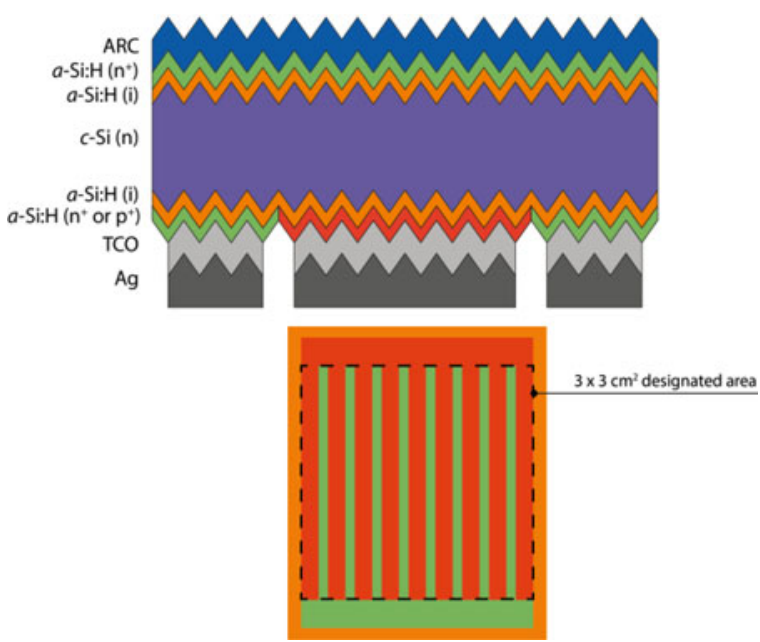

Fig. 1. Cross-sectional (top) and bottom view (bottom) of our IBC-SHJ solar cell (not to scale).

regions have indeed a reduced probability of being efficiently collected by the hole collector, due to the several $100-\mu \mathrm{m}$-long spacing between the electron- and hole-collecting regions. This can result in $J_{\mathrm{sc}}$ losses. This effect is known as electrical shading and has been extensively investigated both for homojunction and heterojunction back-contacted devices [32]-[34]. Eventually, back-contacted SHJ devices require bulk materials with sufficiently long carrier diffusion lengths to perform at their best [35], [36].

To quantify the losses resulting from these different mechanisms, an in-depth investigation of the $J_{\mathrm{sc}}$ losses in backcontacted SHJ devices is needed. In this contribution, we therefore aim at 1) proposing a complete analysis of the $J_{\mathrm{sc}}$ losses in back-contacted SHJ devices and 2) providing practical guidelines to mitigate these losses, hence increasing the $J_{\mathrm{sc}}$ in actual devices. Regarding this latter point, we focus on the reduction of the reflection and parasitic absorption losses at the front side of back-contacted SHJ solar cells. As a result of our optimization, we obtained a $J_{\mathrm{sc}}$ gain of $1.0 \mathrm{~mA} / \mathrm{cm}^{2}$ compared with our previous best device, yielding a conversion efficiency of $22.0 \%$ with a $J_{\mathrm{sc}}$ of $40.9 \mathrm{~mA} / \mathrm{cm}^{2}$.

\section{EXPERIMENTAL DETAILS}

\section{A. Interdigitated Back-Contacted Silicon Heterojunction Solar Cells Processing}

Interdigitated back-contacted silicon heterojunction solar cells (IBC-SHJ) were fabricated on n-type, 250- $\mu$ m-thick, $3-\Omega \cdot \mathrm{cm}, 4$-in float-zone wafers. The active cell area is $9.0 \mathrm{~cm}^{2}$, excluding the busbar area. A schematic of our standard device structure is depicted in Fig. 1. It features a pitch of $2.6 \mathrm{~mm}$, with 1.6-mm-wide hole-collecting fingers and $1.0-\mathrm{mm}$-wide electron-collecting regions. No gap was left between the holeand the electron-collecting regions. This does not lead to shunt losses due to the low conductivity of the a-Si:H layers. The respective metallization fingers for hole and electron collection are separated by a gap of $300 \mu \mathrm{m}$. 
TABLE II

DESCRIPTION OF THE IBC-SHJ DEVICES PROCESSED IN THIS PAPER

\begin{tabular}{lcc}
\hline \hline $\begin{array}{l}\text { IBC-SHJ } \\
\text { device }\end{array}$ & $\begin{array}{c}\text { n-type a-Si:H layer } \\
\text { thickness at front [nm] }\end{array}$ & $\begin{array}{c}\text { ARC } \\
\text { scheme }\end{array}$ \\
\hline$\# 1$ & 12 & single-layer a-SiN $\mathrm{x}: \mathrm{H}$ \\
$\# 2$ & 6 & \\
$\# 3$ & 1 & \\
$\# 4$ & 0 & $\mathrm{a}-\mathrm{SiN}_{\mathrm{x}}: \mathrm{H} / \mathrm{a}-\mathrm{SiO}_{\mathrm{x}}: \mathrm{H}$ DARC \\
$\# 5$ & 6 & \\
$\# 6$ & 0 & \\
\hline \hline
\end{tabular}

Following saw-damage etching, alkaline texturing, and chemical cleaning, the wafers were shortly dipped into a 5\% hydrofluoric acid solution for oxide etching and loaded into our plasma-enhanced chemical vapor deposition (PECVD) tool. We used an OctopusII system from INDEOtec SA. We deposited a stack consisting of an intrinsic a-Si:H layer capped with an n-type a-Si:H layer at the device front side, and a single intrinsic a-Si:H passivation layer was deposited at the back. These layers have typical thickness as used in two-side contacted SHJ devices (5-10 nm). Patterned p- and n-type a-Si:H fingers were afterwards plasma-deposited at the back, using in-situ shadow masking. The device front side was eventually completed by plasma-depositing a 75-nm-thick hydrogenated amorphous silicon nitride $\left(\mathrm{a}-\mathrm{SiN}_{\mathrm{x}}: \mathrm{H}\right) \mathrm{ARC}$ layer. All a-Si:H and a-SiN $\mathrm{x}: \mathrm{H}$ layers were deposited at $200^{\circ} \mathrm{C}$. To fabricate the rear electrodes, we deposited a TCO/Ag stack on the full rear side using physical vapor deposition. The patterning into electron- and hole-collecting electrodes was achieved by a combination of hot-melt inkjet printing and wet-chemical etching. Hot-melt inkjet printing was performed by the commercial system LP50 from Roth \& Rau B. V. Finally, the solar cells were cured at $200^{\circ} \mathrm{C}$ in a belt furnace to heal potentially present sputter-induced damage of the a-Si:H layers [37]. Further experimental details can be found in [14] and [38], especially regarding the low-cost patterning processes we developed.

The actual optimization of the $J_{\mathrm{sc}}$ of our devices starts from the baseline process flow described above. Several steps were then independently varied. First, we tested four different thicknesses for the front-side n-type a-Si:H layer, namely 12, 6, 1, and $0 \mathrm{~nm}$ (i.e., no front n-layer at all). Second, we investigated the use of a double-layer ARC (DARC) instead of the baseline single-layer a-SiN $\mathrm{N}_{\mathrm{x}} \mathrm{H}$ ARC. This DARC consists of a 62-nm-thick layer of a-SiN $\mathrm{S}_{\mathrm{x}} \mathrm{H}$, capped with an 88-nm-thick hydrogenated amorphous silicon oxide $\left(\mathrm{a}-\mathrm{SiO}_{\mathrm{x}}: \mathrm{H}\right)$ layer. The refractive index of these layers is 1.87 and 1.46 at a wavelength of $630 \mathrm{~nm}$, respectively. Finally, a device featuring only an intrinsic a-Si:H layer at the front (no n-type a-Si:H layer) and a DARC was processed, aiming at reaching high $J_{\mathrm{sc}}$. Table II summarizes the characteristics of the aforementioned IBC-SHJ devices.

For reference, the performance of our IBC-SHJ devices was compared with that of a two-side contacted FE-SHJ solar cell processed in our laboratory, already reported in [24]. At the front side, this FE-SHJ device features a thin intrinsic/p-type a-Si:H layer, a highly-transparent IO:H/ITO stack, and a screen-printed

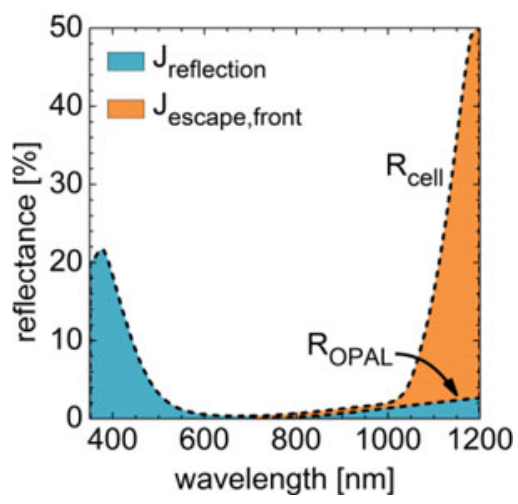

Fig. 2. Reflection spectrum experimentally measured $\left(R_{\text {cell }}\right)$ on an actual IBC-SHJ solar cell and OPAL-simulated $\left(R_{\mathrm{OPAL}}\right)$ reflection spectrum accounting only for the front side of the same device. The two curves usually start to differ from $850 \mathrm{~nm}$ on. The area to be integrated over the AM1.5G spectrum to calculate the reflection losses ( $\left.J_{\text {reflection }}\right)$ and the amount of light escaping at the front ( $\left.J_{\text {escape,front }}\right)$ is also shown.

metal grid with $4 \%$ metallized area fraction. On the rear side, a full-area $\mathrm{TCO} / \mathrm{metal}$ electrode is used.

\section{B. Solar Cells Characterization and Simulation}

The current-voltage $(I-V)$ characteristics of our solar cells were measured in-house on a Wacom WXS-90S-L2 system using standard test conditions at $25{ }^{\circ} \mathrm{C}$ under 1-sun AM1.5G equivalent illumination. We defined a $3 \mathrm{~cm} \times 3 \mathrm{~cm}$ designated area using a shadow mask, excluding the busbar area (see Fig. 1). The shadow mask area is defined with an accuracy better than $0.05 \mathrm{~cm}^{2}$. We used an aluminum-anodized black chuck specifically designed to provide an alignment accuracy of $\pm 50 \mu \mathrm{m}$ between the device under test and the shadow mask. We measured the pseudo fill-factor $(p \mathrm{FF})$ values of our devices using a Suns- $V_{\text {oc }}$ tool from Sinton Instruments [39].

The external quantum efficiency (EQE) curves of the devices were measured using the IQE-SCAN system from PV-tools. The spot area is $2 \mathrm{~cm} \times 2 \mathrm{~cm}$. Solar cells were measured under a 0.5 -sun light bias, at a chopping frequency of $230 \mathrm{~Hz}$. These settings ensure that there is $<2 \%$ relative difference between the $J_{\mathrm{sc}}$ measured on the $I-V$ setup and the one calculated from the EQE curve.

The solar cells reflectance $\left(R_{\text {cell }}\right)$ and transmission $\left(T_{\text {cell }}\right)$ spectra were measured using a Lambda950 spectrometer from PerkinElmer. The solar cell total absorbance $\left(A_{\text {cell }}\right)$ is then calculated as $A_{\text {cell }}=1-\left(R_{\text {cell }}+T_{\text {cell }}\right)$.

We used the OPAL software [40] to calculate the theoretical reflectance $\left(R_{\mathrm{OPAL}}\right)$ and absorbance $\left(A_{\mathrm{OPAL}}\right)$ spectra for the front a-Si:H and ARC layers used in our SHJ devices. The refractive index and absorption-coefficient spectra of our layers required for these simulations were acquired using a Horiba UVISEL ellipsometer. As OPAL assumes semi-infinite substrates, the simulated $R_{\mathrm{OPAL}}$ spectrum does not account for long wavelength light internally reflected at the rear side of the wafer. The comparison of the OPAL-simulated reflection spectrum with the one measured on the actual device (see Fig. 2) thus allows us to separate the reflection losses due merely to the front 
stack from those due to the long-wavelength light internally reflected at the back. In the case of the IBC-SHJ devices processed in our laboratory, the $R_{\mathrm{OPAL}}$ and $R_{\text {cell }}$ spectra usually start to differ from $850 \mathrm{~nm}$ on.

\section{Calculation of Short-Circuit Current Losses}

We calculated the $J_{\mathrm{sc}}$ losses in our SHJ solar cells by integrating the area between the $\mathrm{EQE}$ and the absorbance $\left(A_{\text {cell }}\right.$; see Section II-B) curves over the AM1.5G solar spectrum. The general expression for the calculation of the $J_{\mathrm{sc}}$ losses $\left(J_{\text {loss }}\right)$ has the following form:

$$
J_{\text {loss }}=\frac{q}{h c} \int_{\lambda_{1}}^{\lambda_{2}} \lambda \cdot \Phi(\lambda) \cdot\left[A_{\text {cell }}(\lambda)-\operatorname{EQE}(\lambda)\right] \cdot d \lambda
$$

where $q$ is the elementary charge, $h$ is Planck's constant, $c$ is the speed of the light, $\lambda$ is the photon wavelength, and $\Phi(\lambda)$ is the AM1.5G solar spectrum. $\lambda_{1}$ and $\lambda_{2}$ are the outer bounds of the range for which the $J_{\text {loss }}$ calculation is performed. The values of $\lambda_{1}$ and $\lambda_{2}$ are reported in the Appendix.

To facilitate the discussion, current losses are grouped into external and internal losses, as also proposed in [3], [4], and [41]. External losses are optical losses which result from light that is not absorbed in the device (e.g., due to reflection or transmission losses) and, thus, does not generate any carrier. In contrast, internal losses result from light that is absorbed in the device, but is then either lost due to internal parasitic absorption (e.g., in the a-Si:H or the TCO layers), or whose generated carriers are lost due to imperfect collection.

Regarding external losses, we distinguish three different mechanisms. At the device front, part of the light is lost due to external reflection. These reflection losses $\left(J_{\text {reflection }}\right)$ are calculated by integrating the OPAL-simulated reflection spectrum of the front side of the IBC-SHJ device under test $\left(R_{\mathrm{OPAL}}\right.$; cf., Section II-B), as shown in Fig. 2. At the back side of the device, part of the long wavelength light is lost by transmission through the gaps between the rear electrodes (300- $\mu$ m-wide; see Section II-A), whereas another part is internally reflected toward the front side, where part of it further escapes. The former is called escape light at the back ( $\left.J_{\text {escape,back }}\right)$, and the latter escape light at the front $\left(J_{\text {escape,front }}\right)$. $J_{\text {escape,back }}$ is calculated by integrating the transmission curve of the cell. $J_{\text {escape,front }}$ is calculated by integrating the area between the $R_{\text {cell }}$ (the measured solar cell reflectance) and the $R_{\mathrm{OPAL}}$ curves at wavelengths $>850 \mathrm{~nm}$, as illustrated in Fig. 2.

Note that in the case of two-side contacted SHJ devices, a fourth external loss mechanism exists, namely the effective shadowing losses ( $\left.J_{\text {shadowing }}\right)$ due to the front metal grid. When required, we calculated $J_{\text {shadowing }}$ as the difference between the 1 -sun $J_{\mathrm{sc}}$ measured on the actual device and the $J_{\mathrm{sc}}$ calculated by integrating the EQE curve measured on a front electrode-free device, purposely fabricated for spectral response measurement. On this device, the EQE is measured by placing the probes directly on the front TCO. The lateral conductivity of this layer is sufficient to carry out an EQE measurement.

Internal losses can be broken down according to the spectral region in which they occur. In our analysis (similarly to

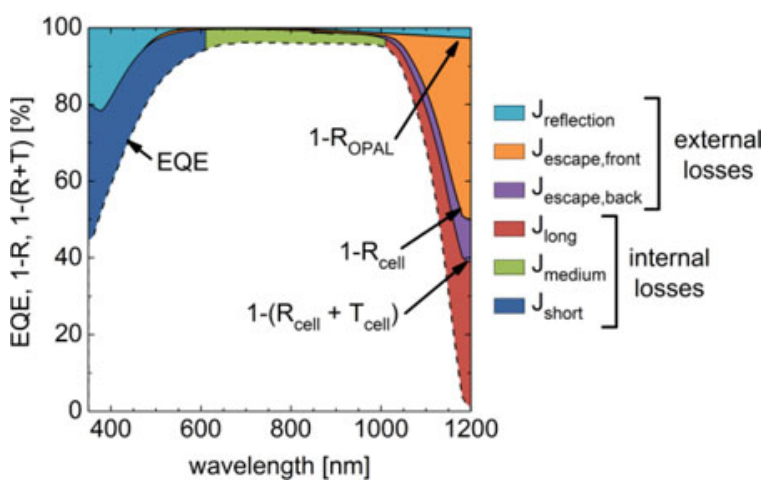

Fig. 3. Illustrative example of $J_{\mathrm{sc}}$ loss sources in our IBC-SHJ solar cell.

[3] and [4]), we discerned between short-wavelength current losses, corresponding to the wavelength integration range between 350 and $600 \mathrm{~nm}\left(J_{\text {short }}\right)$, medium wavelength losses in the range $600-1000 \mathrm{~nm}\left(J_{\text {medium }}\right)$, and long-wavelength losses in the range $1000-1200 \mathrm{~nm}\left(J_{\text {long }}\right)$. $J_{\text {short }}$ hence accounts for the losses occurring in the ultraviolet and the blue part of the spectrum, $J_{\text {medium }}$ in the visible range, and $J_{\text {long }}$ in the infrared region. For the sake of clarity, all these loss sources are exemplarily depicted in Fig. 3, and the corresponding formulas are detailed in Table V in the Appendix.

The actual $J_{\mathrm{sc}}$ of the device can finally be retrieved by subtracting the sum of all $J_{\mathrm{sc}}$ losses to the available photocurrent $\left(J_{\mathrm{ph}}\right)$, where $J_{\mathrm{ph}}$ is given by the integration of the AM1.5G spectrum over 350-1200 $\mathrm{nm}$, which equals $45.9 \mathrm{~mA} / \mathrm{cm}^{2}$, assuming that each photon in this spectral region generates one electron-hole pair and each generated charge carrier is successfully separated and collected. This assumption does not take into account impact ionization effects occurring at short wavelengths, which can lead to quantum efficiencies exceeding unity [42], [43]. Thus, assuming $J_{\mathrm{ph}}=45.9 \mathrm{~mA} / \mathrm{cm}^{2}$ might actually result in a slight underestimation of the actual maximum $J_{\mathrm{sc}}$ for an infinitely thick Si solar cell. Quantum efficiency values higher than one have been recently observed in homojunction back-contacted devices [30].

Importantly, our $J_{\mathrm{sc}}$ losses are thus calculated with respect to this available photocurrent $J_{\mathrm{ph}}=45.9 \mathrm{~mA} / \mathrm{cm}^{2}$. This value does not account for the finite thickness of the actual device and thus should not be considered as a maximum value for the achievable $J_{\mathrm{sc}}$ of practical devices. Detailed analysis of the theoretical limits of $J_{\mathrm{sc}}$ in solar cells can be found elsewhere [44], [45].

\section{RESULTS AND DISCUSSION}

\section{A. Breakdown of Short-Circuit Current Losses: Two-Side Contacted Versus Interdigitated Back-Contacted Silicon Heterojunction Solar Cells}

Table III gives the electrical parameters of two reference FESHJ and IBC-SHJ solar cells processed in our laboratory and reported in [24] and [14], respectively. Their EQE, $R_{\text {cell }}, T_{\text {cell }}$, and $A_{\text {cell }}$ curves are displayed in Fig. 4. Notice that the transmission curve of the FE-SHJ solar cell is zero, as it features a 
TABLE III

ONE-SUn $I-V$ PARAMETERS OF THE REFERENCE FE-SHJ AND IBC-SHJ SOLAR CELLS PROCESSED IN OUR LABORATORY AND OBJECTS OF THE $J_{\text {Sc }}$ LOSSES ANALYSIS PRESENTED IN THIS PAPER

\begin{tabular}{lcccc}
\hline \hline Device & $J_{\mathrm{sc}}\left[\mathrm{mA} / \mathrm{cm}^{2}\right]$ & $V_{\mathrm{oc}}[\mathrm{mV}]$ & $\mathrm{FF}[\%]$ & Eff. [\%] \\
\hline FE-SHJ [24] & 38.9 & 727 & 78.4 & $22.1^{*}$ \\
IBC-SHJ [14] & 39.9 & 724 & 74.5 & $21.5^{* *}$ \\
\hline \hline
\end{tabular}

*certified by Fraunhofer ISE CalLab; ${ }^{*}$ in-house measurement.

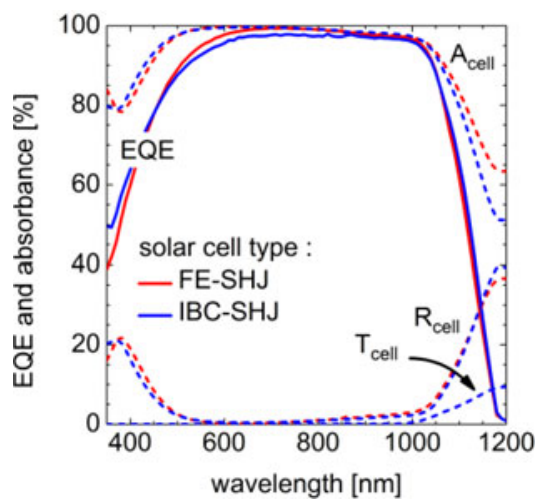

Fig. 4. EQE, reflection, transmission, and absorbance curves of the reference FE-SHJ and IBC-SHJ solar cells processed in our laboratory. Notice that the $\mathrm{EQE}$ curve for the FE-SHJ device does not account for the shadowing losses, as it is measured on a front electrode-free device, as explained in Section II-C.

fully metallized rear side (see Section II-A) so that no light is transmitted. In addition, the EQE curve of the FE-SHJ device does not account for the shadowing losses, as it is measured on a front electrode-free device, as explained in Section II-C.

As seen from Fig. 4, the EQE curves of the two solar cells are quite similar. Conversely, their absorbance curves mainly differ in the long-wavelength region: At $1200 \mathrm{~nm}$, the IBC-SHJ device features $15 \%$ abs less absorbance than its FE-SHJ counterpart. This is related to long-wavelength light transmitted through the IBC-SHJ device.

Using the method outlined in Section II-C, we now calculate and compare the $J_{\mathrm{sc}}$ losses of both solar cells; the results are presented in Fig. 5. The total $J_{\text {sc }}$ loss for the FE-SHJ solar cell amounts to $6.9 \mathrm{~mA} / \mathrm{cm}^{2}$, compared with $5.9 \mathrm{~mA} / \mathrm{cm}^{2}$ for the IBC-SHJ solar cell, thus giving a $1.0-\mathrm{mA} / \mathrm{cm}^{2}$ loss difference between the two structures. This is consistent with the $J_{\mathrm{sc}}$ difference experimentally measured on the two devices (see $I-V$ measurements; Table III).

Having a closer look at the $J_{\mathrm{sc}}$ loss breakdown in Fig. 5, it can be noticed that while most of the losses are common to the two structures (FE- and IBC-SHJ solar cells), some are architecturespecific. First of all, obviously, there is no front-electrode shadowing loss for the IBC-SHJ solar cell. This alone represents a potential gain of about $1.3 \mathrm{~mA} / \mathrm{cm}^{2}$ (equal to the amount of effective shadowing losses in the FE-SHJ device) for backcontacted devices, provided that these extra-generated carriers are efficiently collected. However, after the module encapsulation of two-side contacted solar cells, the effective shadowing losses are reduced by $50 \%$, owing to the light recycling between

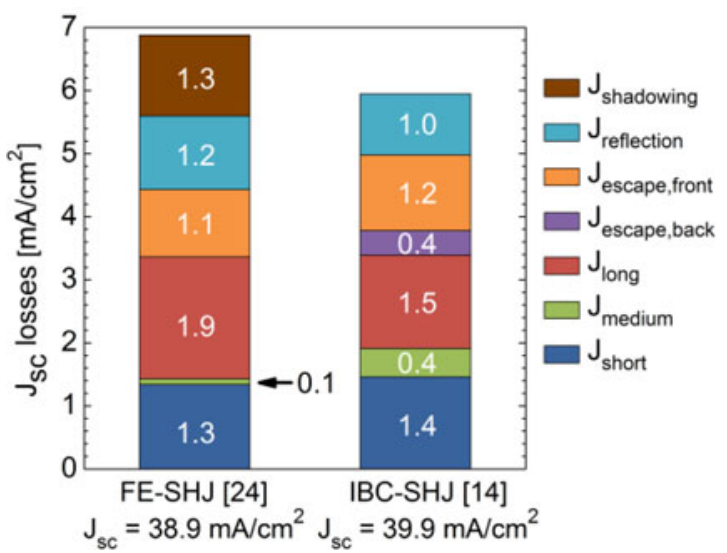

Fig. 5. Comparison of short-circuit current losses in the reference FE-SHJ and IBC-SHJ solar cells processed in our laboratory, calculated with respect to the available photocurrent $J_{\mathrm{ph}}=45.9 \mathrm{~mA} / \mathrm{cm}^{2}$.

the metal grid and the front glass [46]. Moreover, several strategies have been proven to efficiently reduce the shadowing losses at solar cell level already, such as copper plating [6]-[8] or the SmartWire technology [47], to name a few. The final gain for back-contacted devices resulting from the suppression of the front shadowing losses is thus difficult to ascertain at module level.

In contrast with shadowing losses, light escaping at the back is a peculiar feature of the IBC-SHJ device. As seen in Fig. 4, this loss is caused by light escaping at the back of the IBCSHJ solar cell through the gap between the fingers of the back electrodes. In contrast, this phenomenon is not present in the FE-SHJ solar cell featured in this paper. Indeed, as mentioned in Section II-A, its rear side is fully metallized, and thus, no light escapes at the back. ${ }^{1}$ However, this does not mean that the FE-SHJ solar cell makes better use of this part of light: Indeed, an important amount of it is lost within the $\mathrm{TCO} /$ metal rear stack due to plasmonic absorption and, thus, contributes to longwavelength parasitic absorption [3], [4], as further discussed below in this section. In the IBC-SHJ device presented here, $J_{\text {escape,back }}$ amounts to $0.4 \mathrm{~mA} / \mathrm{cm}^{2}$ and represents $1 \%$ of the total $J_{\mathrm{sc}}$ of the solar cell. This value is consistent with what has been observed on other back-contacted structures, such as SunPower's A-300 solar cells [48].

Besides $J_{\text {shadowing }}$ and $J_{\text {escape,back, }}$, all the remaining $J_{\text {sc }}$ loss terms are present in both device architectures. Front-side reflection losses are found to be rather similar in both device architectures. This is expected, as the two solar cells are both based on a single-layer ARC with comparable refractive indices, even though this ARC is a-SiN $: \mathrm{H}$ in the case of the IBC-SHJ device, whereas it is an IO:H/ITO stack in the FE-SHJ device [49]. This is further supported by the very resembling reflection curves of the two solar cells in the short-wavelength region (see Fig. 4).

Short-wavelength losses are virtually identical for both solar cells, totalizing about $1.4 \mathrm{~mA} / \mathrm{cm}^{2}$. This is consistent, as both

\footnotetext{
${ }^{1}$ This situation would nevertheless be different in the case of bifacial SHJ solar cells [2]: Indeed, such devices would also feature light escaping at the rear side.
} 
devices feature a-Si:H layers with similar thicknesses at the front. However, whereas the front $a-\mathrm{Si}: \mathrm{H}$ layers of our champion FE-SHJ device presented here have already been purposely optimized to reach high $J_{\mathrm{sc}}$, the front side of our IBC-SHJ solar cell under investigation had yet to be subject to any $J_{\mathrm{sc}}$ optimization. Importantly, this result underlines that our IBC-SHJ device could benefit from careful further optimization of its front side. This topic is developed in more detail in Section III-B.

Optical losses occurring in the medium part of the spectrum are rather small in both cases. They appear to be higher for the IBC-SHJ solar cell than for the FE-SHJ device: 0.4 versus $0.1 \mathrm{~mA} / \mathrm{cm}^{2}$, respectively. This difference may be attributed to electrical shading losses, usually occurring above the electron-collecting regions in back-contacted devices [32] [34]. It is well known that the narrower the electron-collecting stripes, the lower the electrical shading [50]. In this regard, redesigning the back side of our IBC-SHJ devices, with narrower electron-collecting regions, might help to mitigate such losses. However, achievable designs are ultimately limited by the practically feasible patterning techniques for the a-Si:H layers and the rear electrodes. In our case, it seems reasonable to consider 0.5 -mm-wide electron-collecting stripes as a practical limit for our process flow. Alternatively, as the electrical shading is also dependent on the surface-passivation level of the electron-collecting regions [33], it can be reduced by enhancing the passivation quality in our IBC-SHJ devices. To which quantitative extent these two levers will allow mitigating $J_{\text {medium }}$ still needs to be investigated.

Long-wavelength losses are found to be higher for the FESHJ solar cell than for the IBC-SHJ device, with 1.9 versus $1.5 \mathrm{~mA} / \mathrm{cm}^{2}$, respectively. As detailed in [51] and [52], these long-wavelength losses mainly owe to the parasitic absorption in the rear TCO/metal electrode. The EQE of the two solar cells being virtually identical, the smaller $J_{\text {long }}$ value of the IBC-SHJ solar cell mainly stems from its reduced absorbance at long wavelength. ${ }^{2}$ As already discussed above, the reduced absorbance of the IBC-SHJ solar cell at long wavelength is due to the light being partly transmitted through the rear electrodes. In other words, it means that for the IBC-SHJ device, $J_{\text {long }}$ is smaller because part of the long wavelength light is already anyhow lost due to transmission losses, these latter being accounted for in $J_{\text {escape,back }}$. Interestingly, the sum of $J_{\text {long }}$ and $J_{\text {escape,back }}$ for the IBC-SHJ device $\left(1.5\right.$ and $0.4 \mathrm{~mA} / \mathrm{cm}^{2}$, respectively; see Fig. 5) equates to $J_{\text {long }}$ for the FE-SHJ solar cell, namely $1.9 \mathrm{~mA} / \mathrm{cm}^{2}$. This highlights that the reduced $J_{\text {long }}$ for the former device is compensated by an equivalent increase

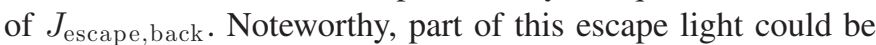
recycled at module level, e.g., by using a white back sheet or paint [48].

For the sake of completeness, we also emphasize that quantitatively, the $J_{\mathrm{sc}}$ loss analysis done in this section is mainly representative for the specific case of our SHJ devices. Indeed, high- $J_{\mathrm{sc}}$ two-side contacted SHJ devices such as the ones pro-

\footnotetext{
${ }^{2}$ Indeed, $J_{\text {long }}$ is proportional to the area between the EQE and the absorbance curves (see its formula in Table V in the Appendix). Hence, in case of identical EQE curves, the lower the absorbance, the smaller $J_{\text {long }}$.
}
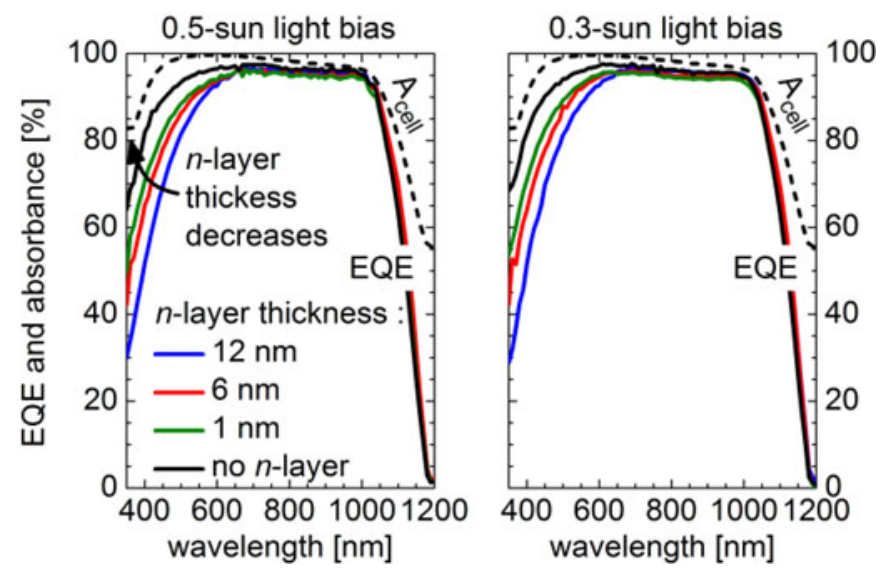

Fig. 6. EQE curves of IBC-SHJ devices with various thicknesses of n-type a-Si:H layer at the front $(0,1,6$, and $12 \mathrm{~nm}$; see devices \#1 to \#4 in Table II), under a light bias of 0.5 sun (left) and 0.3 sun (right). We also reported the measured absorbance curve (identical for all the solar cells within this batch).

duced by Panasonic [2] or Kaneka [6] would surely feature a different $J_{\mathrm{sc}}$ loss breakdown. However, qualitatively, our methodology holds for every possible device and, thus, serves as a fair term of comparison to identify and mitigate the $J_{\mathrm{sc}}$ losses in our IBC-SHJ solar cells.

Overall, our $J_{\mathrm{sc}}$ loss analysis reveals that with the exception of escape light at the back (and to a lesser extent $J_{\text {medium }}$ losses), our IBC-SHJ solar cells suffer from similar loss mechanisms as our two-side contacted FE-SHJ devices. As a consequence, most of the solutions already proposed to mitigate the $J_{\mathrm{sc}}$ losses on two-side contacted FE-SHJ solar cells also hold for backcontacted SHJ devices. An additional salient asset of the backcontacted architecture is that no carriers are collected at the front; this reduces significantly the constraints when optimizing the front side, as already discussed in Section I.

\section{B. Mitigation of Short-Circuit Current Losses at the Front of Interdigitated Back-Contacted Silicon Heterojunction Devices}

Following the analysis presented in Section III-A, we started the mitigation of the $J_{\mathrm{sc}}$ losses in our IBC-SHJ devices tackling the parasitic absorption occurring at the front side. The left side of Fig. 6 shows the EQE curves of IBC-SHJ devices \#1 to \#4, with various n-type a-Si:H layer thicknesses at the front (see Table II), under a light bias of 0.5 sun. The thinner the n-type a$\mathrm{Si}: \mathrm{H}$ layer at the front, the higher the EQE at short wavelengths. This clearly results from reduced parasitic absorption in the thinner a-Si:H stack at the front.

It is well known that EQE data for both homojunction and heterojunction back-contacted devices can feature strong illumination dependences [11], [53], [54]. This is the case when the surface recombination velocity at the front side is highly sensitive to the (excess) carrier density. In our case, we did not notice any change on the EQE of our IBC-SHJ devices \#1 to \#4 down to a light bias of 0.3 sun, as illustrated on the right side of Fig. 6. Remarkably, the trend observed at a light bias of 0.5 sun is also conserved at lower light bias: the thinner the n-layer, the higher the EQE at short wavelength. This suggests that our 


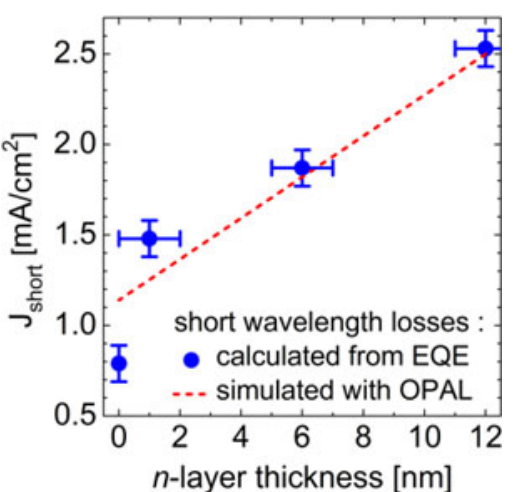

Fig. 7. Short-wavelength losses as a function of the front n-type a-Si:H layer thickness. As a comparison, we reported the values obtained with OPAL simulations.

TABLE IV

Optical Losses of Two IBC-SHJ SOLAR Cells With DifFERENT ARC SCHEMES ON THE FRONT SIDE

\begin{tabular}{lccc}
\hline \hline $\begin{array}{l}\text { IBC-SHJ } \\
\text { device }\end{array}$ & $\begin{array}{c}\text { ARC } \\
\text { scheme }\end{array}$ & $\begin{array}{c}J_{\text {reflection }}\left[\mathrm{mA} / \mathrm{cm}^{2}\right] \\
\# 2\end{array}$ & $\begin{array}{c}J_{\text {escape,front }} \\
{\left[\mathrm{mA} / \mathrm{cm}^{2}\right]}\end{array}$ \\
\hline$\# 5$ & $\begin{array}{c}\text { single-layer a-SiN } \mathrm{x} \\
\text { a-SiN } \mathrm{H} \text { :H/a-SiO }\end{array}$ & 1.0 & 1.2 \\
\hline \hline
\end{tabular}

front-side passivation is relatively insensitive to the generated carrier density.

From the EQE curves on the left side of Fig. 6, we calculated the resulting $J_{\text {short }}$ losses, as already detailed in Section II-C. The results are reported in Fig. 7. $J_{\text {short }}$ is dramatically reduced when decreasing the front $\mathrm{n}$-type a-Si:H layer thickness. For instance, replacing the 6-nm-thick n-type a-Si:H layer (featured at the front of the IBC-SHJ device on which we reported in [14]) with no n-layer at all, represents a current gain of $\sim 1.0 \mathrm{~mA} / \mathrm{cm}^{2}$. These $J_{\text {short }}$ values are consistent with those obtained using OPAL, especially for n-layers thicker than $6 \mathrm{~nm}$. It thus suggests that for these thicknesses, $J_{\text {short }}$ is completely dominated by parasitic absorption losses, and that recombination at the device front side plays a minor role. In contrast, we think that the discrepancies between the experimental and the simulated values of $J_{\text {short }}$ for the smallest n-layer thicknesses are mainly due to the uncertainty in accurately measuring the optical properties and the thickness of a-Si:H layers thinner than $\sim 2 \mathrm{~nm}$.

We now address the reflection losses at the front of our IBC-SHJ devices. Table IV gives the values of $J_{\text {reflection }}$ and $J_{\text {escape,front }}$ calculated for the IBC-SHJ solar cells \#2 and \#5, featuring either the standard single-layer $\mathrm{a}-\mathrm{SiN}_{\mathrm{x}}: \mathrm{H}$ ARC or the $\mathrm{a}-\mathrm{SiN}_{\mathrm{x}}: \mathrm{H} / \mathrm{a}-\mathrm{SiO}_{\mathrm{x}}: \mathrm{H}$ DARC scheme.

$J_{\text {reflection }}$ is reduced by $0.4 \mathrm{~mA} / \mathrm{cm}^{2}$ when using the DARC scheme, owing to its overall reduced reflectance over the spectral range of interest. In contrast, $J_{\text {escape }}$, front results $0.2 \mathrm{~mA} / \mathrm{cm}^{2}$ higher than with the single-layer ARC. This again is due to the lower reflectance of the DARC scheme, especially in the longwavelength spectral region. Indeed, as more light is coupled into the wafer, more light is reflected at the wafer rear side, and eventually, $J_{\text {escape,front }}$ increases. In the end, the resulting net

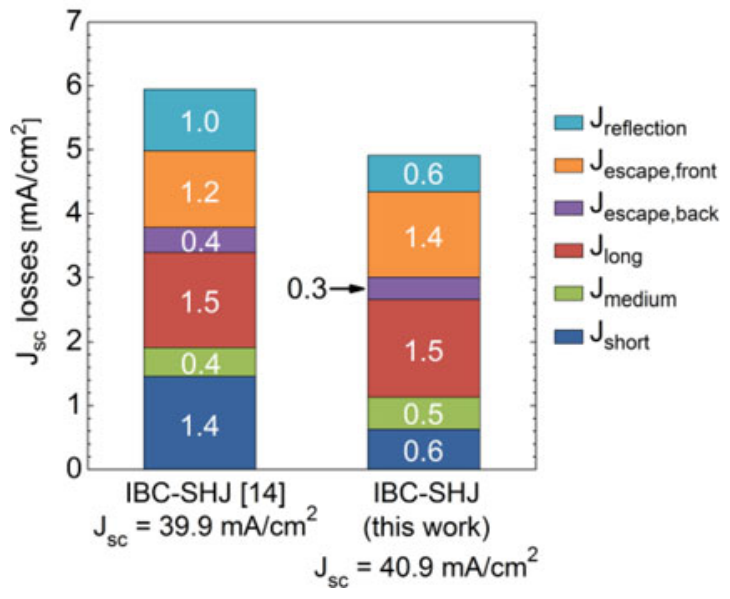

Fig. 8. $J_{\mathrm{sc}}$ loss breakdown for our previous best IBC-SHJ device (with $J_{\mathrm{sc}}=$ $39.9 \mathrm{~mA} / \mathrm{cm}^{2}$; see [14]) and our new $J_{\mathrm{sc}}$-optimized device, featuring a $J_{\mathrm{sc}}$ of $40.9 \mathrm{~mA} / \mathrm{cm}^{2}$ (this publication).

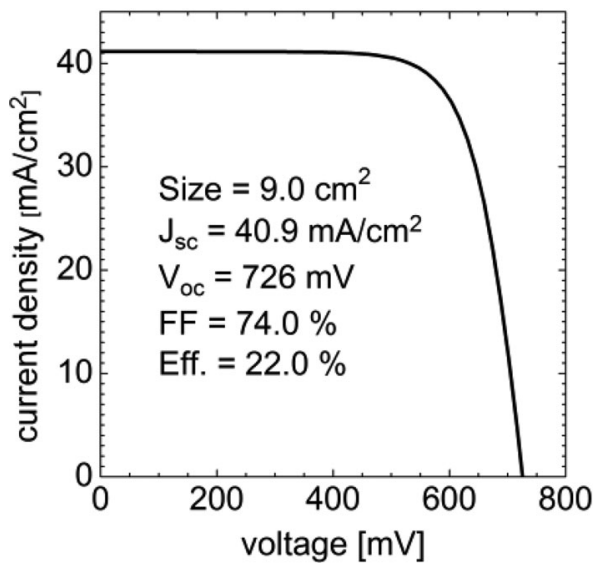

Fig. 9. $I-V$ characteristic of our new best IBC-SHJ solar cell (in-house measurement).

$J_{\mathrm{sc}}$ gain when using the DARC scheme will, therefore, be close to $0.2 \mathrm{~mA} / \mathrm{cm}^{2}$.

\section{High- $J_{\mathrm{sc}}$ Interdigitated Back-Contacted Silicon Heterojunction Device}

Taking benefit from the points discussed in Section III-B, we processed an IBC-SHJ device featuring a DARC but no n-type a-Si:H layer at the front (device \#6; see Table II). Its $J_{\mathrm{sc}}$ loss breakdown is reported in Fig. 8 and is compared with our previous best IBC-SHJ device (already reported in Fig. 5).

As a result of the removal of the n-type a-Si:H layer at the front and the use of the DARC scheme, $J_{\text {short }}$ and $J_{\text {reflection }}$ are reduced by 0.8 and $0.4 \mathrm{~mA} / \mathrm{cm}^{2}$, respectively. In contrast, $J_{\text {escape,front }}$ losses are $0.2 \mathrm{~mA} / \mathrm{cm}^{2}$ higher in the high- $J_{\mathrm{sc}}$ device. These values are in good agreement with the outcomes of Section III-B (see especially Fig. 7 and Table IV). All other losses remain virtually identical. Overall, the $J_{\mathrm{sc}}$ losses are, hence, reduced by $1.0 \mathrm{~mA} / \mathrm{cm}^{2}$ in this new device.

Fig. 9 plots the $I-V$ curve of our $J_{\mathrm{sc}}$-optimized IBC-SHJ device \#6. It features a $J_{\mathrm{sc}}$ of $40.9 \mathrm{~mA} / \mathrm{cm}^{2}$, which is $1.0 \mathrm{~mA} / \mathrm{cm}^{2}$ higher than for our previous best device. This is in good 
agreement with the values obtained from the $J_{\mathrm{sc}}$ loss analysis presented in Fig. 8. As can be seen, the $J_{\mathrm{sc}}$ gain was not obtained at the expenses of the other parameters, as this cell features an efficiency of $22.0 \%$, with a $V_{\text {oc }}$ of $726 \mathrm{mV}$ and an FF of $74.0 \%$. As already emphasized in [14], the transport losses at the two heterocontacts remain the major FF limitation in our IBC-SHJ devices.

These results indicate that the FSF passivation induced by the front n-type a-Si:H layer is not imperatively required for efficient IBC-SHJ devices. Indeed, we did not notice losses neither in FF nor in $V_{\text {oc }}$ in our new best IBC-SHJ device without front ntype a-Si:H layer, compared with our previous best IBC-SHJ device with a front $n$-type a-Si:H layer (see [14]). The $p$ FF stays $\geq 81.0 \%$ for all devices, but no particular trend is seen as a function of the n-layer thickness (data not shown). This latter result suggests that the recombination at the front side plays a minor role in the overall recombination losses in our IBC-SHJ devices [29].

Eventually, our findings are not in direct contradiction with earlier published results in which the presence of an FSF was indicated as a requirement 1) for efficient lateral transport of the photogenerated carriers and 2) for low surface recombination velocities [53], [55]. Both mentioned effects indeed depend on the passivation quality provided in absence of the front n-type a-Si:H layer, through the substrate injection level in case 1 and directly in case 2 . In our case, the concomitant achievement of good $J_{\mathrm{sc}}, V_{\mathrm{oc}}$, and $\mathrm{FF}$ values without front n-type a-Si:H layer owes to the fact that our intrinsic a-Si:H layer alone provides extremely high passivation over a wide injection range. However, as the n-type $a$-Si:H layer gets thinner, the a-SiN $\mathrm{x}: \mathrm{H}$ layer deposited at the front side will also provide a field-effect passivation, induced by its positive fixed charges [56], [57]. To which extent this effect is competing with the decreasing field-effect passivation of the thinner n-type a-Si:H layer requires further investigation.

\section{Further Short-Circuit Current Improvements}

Our experimental results evidenced that short-wavelength losses at the front of back-contacted SHJ devices can be dramatically reduced by removing the front n-type a-Si:H layer without encountering $V_{\mathrm{oc}}$ losses, provided that state-of-the-art intrinsic a-Si:H passivating layers are used. An additional gain could thus be expected by further thinning the front intrinsic a-Si:H layer as well. However, it is known to be a tough challenge to maintain efficient passivation when the intrinsic a-Si:H layer thickness drops below $\sim 4 \mathrm{~nm}$ [5]. Such a thin layer would anyway still feature $\sim 0.4 \mathrm{~mA} / \mathrm{cm}^{2}$ of parasitic absorption. To further decrease the short-wavelength losses, it is thus required to seek for alternatives to the standard a-Si:H layer. Possible approaches include wide-bandgap materials such as a-SiO $\mathrm{S}_{\mathrm{x}}: \mathrm{H}$ [9], [58], indirect bandap materials such as $\mu \mathrm{c}-\mathrm{Si}: \mathrm{H}$ [59] and perhaps the use of black silicon surfaces passivated by atomiclayer deposited aluminum oxide [60], [61]. Recently, Wan et al. [62] also demonstrated PECVD a-SiN $\mathrm{S}_{\mathrm{x}}: \mathrm{H}$ layers featuring parasitic absorption less than $0.1 \mathrm{~mA} / \mathrm{cm}^{2}$ and excellent surface passivation. This kind of layers could be a promising candidate for the front side of back-contacted SHJ devices, as it also offers interesting ARC properties in addition to its low absorption and excellent surface passivation. Its compatibility to our IBC-SHJ devices process flow remains, however, to be investigated, e.g., regarding the deposition temperature. Importantly, as already discussed in Section I, the use of aluminum oxide or silicon nitride as front dielectric passivation layers and ARCs could also allow reaching high FF without the use of a diffused FSF [29].

Regarding reflection losses, we shown in Section III-B that replacing the single-layer ARC by a DARC reduces $J_{\text {reflection }}$ by $0.4 \mathrm{~mA} / \mathrm{cm}^{2}$. To further reduce $J_{\text {reflection, multilayer coatings }}$ can be implemented [63]. However, it must be taken into account that each extra layer yields an incrementally smaller gain [64] and notably increases the process complexity. Moreover, after the encapsulation of the solar cell, $J_{\text {reflection }}$ is already efficiently reduced without the need of a DARC, as the polymer foil and the front glass used in the module will play the role of the intermediate refractive index medium. Consequently, the use of multilayer ARCs might be reserved to devices measured under air (i.e., not encapsulated) and aiming at demonstrating high $J_{\mathrm{sc}}$ values, while the actual mitigation of $J_{\text {reflection }}$ should rather take place at the module level.

Besides losses occurring at the front side of back-contacted SHJ devices, the road toward $J_{\mathrm{sc}}$ values $>41.0 \mathrm{~mA} / \mathrm{cm}^{2}$ will require tackling the remaining $J_{\mathrm{sc}}$ loss sources. First on the list would thus be the long-wavelength losses. Indeed, in our $40.9 \mathrm{~mA} / \mathrm{cm}^{2}$ device, they now represent the major $J_{\mathrm{sc}}$ loss mechanism and account for $31 \%$ of the total losses, versus $25 \%$ in the case of our $39.9 \mathrm{~mA} / \mathrm{cm}^{2}$ solar cell. In this frame, it remains to be investigated if the mitigation solutions known for FE- and RE-SHJ devices, such as advanced rear reflectors [3], [51], [65] would also prove to be useful for back-contacted SHJ solar cells. The mitigation of long-wavelength losses will indeed involve the rear TCO that in our IBC-SHJ devices serves as contact for both heterocontacts. Therefore, specific constraints could differentiate the case of back-contacted SHJ devices from two-side contacted SHJ devices.

\section{CONCLUSION}

In this paper, the optical losses of the IBC-SHJ devices fabricated in our laboratory were thoroughly examined and discussed. We found that our IBC-SHJ devices are in overall affected by $J_{\mathrm{sc}}$ loss mechanisms similar to those of two-side contacted SHJ solar cells, such as short-wavelength parasitic absorption in the front passivation layers, reflection losses, and long-wavelength losses in the rear electrodes.

We then provided practical guidelines to mitigate the reflection and parasitic absorption losses occurring at the front side of IBC-SHJ devices. We first demonstrated that removing the front n-type a-Si:H layer yields a dramatic $J_{\text {sc }}$ gain without compromising the $V_{\text {oc }}$ nor the FF of the device. Second, we showed that replacing the single-layer ARC by a DARC provides an additional $J_{\mathrm{sc}}$ gain.

As a result, we processed an IBC-SHJ device featuring a $J_{\mathrm{sc}}$ of $40.9 \mathrm{~mA} / \mathrm{cm}^{2}$. This represents an improvement of $1.0 \mathrm{~mA} / \mathrm{cm}^{2}$ compared with our previous best $J_{\mathrm{sc}}$ result. Importantly, the 
achievement of this high $J_{\mathrm{sc}}$ was not done detrimentally to the other device parameters, as this new best solar cell features a $V_{\text {oc }}$ of $726 \mathrm{mV}$ and an FF of $74.0 \%$, yielding a final efficiency of $22.0 \%$.

Finally, we discussed further possible $J_{\mathrm{sc}}$ improvements. We proposed that further reducing the short-wavelength losses requires to consider alternatives to the standard a-Si:H layers to passivate the front side of back-contacted SHJ devices. Here, we suggested that wide-bandgap materials appear as promising candidates. Further, $J_{\mathrm{sc}}$ optimization in back-contacted SHJ solar cells will have to address long-wavelength losses, as they represent by far the major loss mechanism once the short-wavelength losses are mitigated.

\section{APPENDIX}

TABLE V

Formulas USED IN SECTION II-C to CALCUlate THE SHORT-Circuit CURRENT LoSSES OF IBC-SHJ DEVICES USING THEIR EQE, REFLECTANCE, TRANSMITTANCE, AND ABSORBANCE CURVES

$$
\begin{aligned}
& \hline J_{\text {sc }} \text { loss sources formulas } \\
& J_{\text {reflection }}=\frac{q}{h c} \int_{350 \mathrm{~nm}}^{1200 \mathrm{~nm}} \lambda \cdot \Phi(\lambda) \cdot R_{\text {OPAL }}(\lambda) \cdot d \lambda \\
& J_{\text {escape, front }}=\frac{q}{h c} \int_{850 \mathrm{~nm}}^{1200 \mathrm{~nm}} \lambda \cdot \Phi(\lambda) \cdot\left[R_{\text {cell }}(\lambda)-R_{\text {OPAL }}(\lambda)\right] \cdot d \lambda \\
& J_{\text {escape, back }}=\frac{q}{h c} \int_{850 \mathrm{~nm}}^{1200 \mathrm{~nm}} \lambda \cdot \Phi(\lambda) \cdot T_{\text {cell }}(\lambda) \cdot d \lambda \\
& J_{\text {short }}=\frac{q}{h c} \int_{350 \mathrm{~nm}}^{600 \mathrm{~nm}} \lambda \cdot \Phi(\lambda) \cdot\left[1-R_{\text {cell }}(\lambda)-T_{\text {cell }}(\lambda)-E Q E(\lambda)\right] \cdot d \lambda \\
& J_{\text {medium }}=\frac{q}{h c} \int_{600 \mathrm{~nm}}^{1000 \mathrm{~nm}} \lambda \cdot \Phi(\lambda) \cdot\left[1-R_{\text {cell }}(\lambda)-T_{\text {cell }}(\lambda)-E Q E(\lambda)\right] \cdot d \lambda \\
& J_{\text {long }}=\frac{q}{h c} \int_{1000 \mathrm{~nm}}^{1200 \mathrm{~nm}} \lambda \cdot \Phi(\lambda) \cdot\left[1-R_{\text {cell }}(\lambda)-T_{\text {cell }}(\lambda)-E Q E(\lambda)\right] \cdot d \lambda \\
& \hline
\end{aligned}
$$

$q$ is the elementary charge, $h$ is Planck's constant, $c$ is the speed of the light, and $\Phi(\lambda)$ is the AM1.5G solar spectrum (all other symbols are defined in the text).

\section{ACKNOWLEDGMENT}

The authors would like to thank J. Hermans and Roth \& Rau B. V. for the support in inkjet printing; M. Pickrell and SunChemicals for hot melt supplying; S. Martin de Nicolas, N. Holm, and N. Badel for their support in processing backcontacted devices; and J. Levrat for fruitful discussions on EQE measurements.

\section{REFERENCES}

[1] S. De Wolf, A. Descoeudres, Z. C. Holman, and C. Ballif, "High-efficiency silicon heterojunction solar cells: A review," Green, vol. 2, no. 1, pp. 7-24, Jan. 2012.

[2] M. Taguchi, A. Yano, S. Tohoda, K. Matsuyama, Y. Nakamura, T. Nishiwaki, K. Fujita, and E. Maruyama, "24. 7\% Record efficiency HIT solar cell on thin silicon wafer," IEEE J. Photovoltaics, vol. 4, no. 1, pp. 96-99, Jan. 2014.

[3] Z. C. Holman, A. Descoeudres, S. De Wolf, and C. Ballif, "Record infrared internal quantum efficiency in silicon heterojunction solar cells with dielectric/metal rear reflectors," IEEE J. Photovoltaics, vol. 3, no. 4, pp. 1243-1249, Oct. 2013.

[4] Z. C. Holman, A. Descoeudres, L. Barraud, F. Z. Fernandez, J. P. Seif, S. De Wolf, and C. Ballif, "Current losses at the front of silicon heterojunction solar cells," IEEE J. Photovoltaics, vol. 2, no. 1, pp. 7-15, Jan. 2012.
[5] H. Fujiwara and M. Kondo, "Effects of a-Si:H layer thicknesses on the performance of a-Si:H/c-Si heterojunction solar cells," J. Appl. Phys., vol. 101, no. 5, pp. 054516-1-054516-9, 2007.

[6] J. L. Hernandez, D. Adachi, D. Schroos, N. Valckx, N. Menou, T. Uto, and M. Hino, "High efficiency copper electroplated heterojunction solar cells and modules-The path towards 25\% cell efficiency," in Proc. 28th Eur. Photovoltaic Sol. Energy Conf., 2013, pp. 741-743.

[7] P. Papet, J. Hermans, T. Söderström, M. Cucinelli, L. Andreetta, D. Bätzner, W. Frammelsberger, D. Lachenal, J. Meixenberger, B. Legradic, B. Strahm, G. Wahli, J. Geissbühler, A. Tomasi, C. Ballif, E. Vetter, and S. Leu, "Heterojunction solar cells with electroplated $\mathrm{Ni} / \mathrm{Cu}$ front electrode," in Proc. 28th Eur. Photovoltaic Sol. Energy Conf., 2013, pp. 1976-1979.

[8] J. Geissbühler, S. De Wolf, A. Faes, N. Badel, Q. Jeangros, A. Tomasi, L. Barraud, A. Descoeudres, M. Despeisse, and C. Ballif, "Silicon heterojunction solar cells with copper-plated grid electrodes: Status and comparison with silver thick-film techniques," IEEE J. Photovoltaics, vol. 4 no. 4, pp. 1055-1062, Jul. 2014.

[9] J. Seif, A. Descoeudres, M. Filipič, F. Smole, M. Topič, Z. C. Holman, S. De Wolf, and C. Ballif, "Amorphous silicon oxide window layers for high-efficiency silicon heterojunction solar cells," J. Appl. Phys., vol. 115, no. 2, pp. 024502-1-024502-8, Jan. 2014.

[10] C. Battaglia, S. Martin De Nicolas, S. De Wolf, X. Yin, M. Zheng, C. Ballif, and A. Javey, "Silicon heterojunction solar cell with passivated hole selective $\mathrm{MoO}_{\mathrm{x}}$ contact," Appl. Phys. Lett., vol. 104, pp. 113902-1113902-5, 2014

[11] M. Lu, S. Bowden, U. Das, and R. Birkmire, "Interdigitated back contact silicon heterojunction solar cell and the effect of front surface passivation," Appl. Phys. Lett., vol. 91, no. 6, pp. 063507-1-063507-3, 2007.

[12] K. Masuko, M. Shigematsu, T. Hashiguchi, D. Fujishima, M. Kai, N. Yoshimura, T. Yamaguchi, Y. Ichihashi, T. Mishima, N. Matsubara, T. Yamanishi, T. Takahama, M. Taguchi, E. Maruyama, and S. Okamoto, "Achievement of more than $25 \%$ conversion efficiency with crystalline silicon heterojunction solar cell," IEEE J. Photovoltaics, vol. 4, no. 6, pp. 1433-1435, Nov. 2014.

[13] J. Nakamura, N. Asano, T. Hieda, C. Okamoto, H. Katayama, and K. Nakamura, "Development of heterojunction back contact Si solar cells," IEEE J. Photovoltaics, vol. 4, no. 6, pp. 1491-1495, Nov. 2014.

[14] A. Tomasi, B. Paviet-Salomon, D. Lachenal, S. Martin De Nicolas, A. Descoeudres, J. Geissbühler, S. De Wolf, and C. Ballif, "Backcontacted silicon heterojunction solar cells with efficiency $>21 \%, "$ IEEE J. Photovoltaics, vol. 4, no. 4, pp. 1046-1054, Jul. 2014.

[15] N. Mingirulli, J. Haschke, R. Gogolin, R. Ferré, T. F. Schulze, J. Düsterhöft, N.-P. Harder, L. Korte, R. Brendel, and B. Rech, "Efficient interdigitated back-contacted silicon heterojunction solar cells," Phys. Status Solidi-Rapid Res. Lett., vol. 5, no. 4, pp. 159-161, Apr. 2011.

[16] T. Desrues, S. De Vecchi, G. D’Alonzo, D. Muñoz, and P.-J. Ribeyron, "Influence of the emitter coverage on interdigitated back contact (IBC) silicon hetero-junction (SHJ) solar cells," in Proc. 40th IEEE Photovoltaic Spec. Conf., 2014, pp. 857-861.

[17] S.-Y. Lee, H. Choi, H. Li, K. Ji, S. Nam, J. Choi, S.-W. Ahn, H.-M. Lee, and B. Park, "Analysis of a-Si:H/TCO contact resistance for the Si heterojunction back-contact solar cell," Sol. Energy Mater. Sol. Cells, vol. 120, pp. 412-416, Jan. 2014.

[18] M. A. Green, K. Emery, Y. Hishikawa, W. Warta, and E. D. Dunlop, "Solar cell efficiency tables (version 39)," Prog. Photovoltaics Res. Appl., vol. 20, pp. 12-20, 2012

[19] N. Koide, K. Kimoto, T. Sakai, T. Kuniyoshi, H. Katayama, N. Asano, T. Hieda, and J. Nakamura, "High efficient crystalline Si solar cells with rear heterojunction emitter and antireflective passivation layer," presented at the 23rd Int. Photovoltaic Sci. Eng. Conf. Asia PVSEC, Taipei, Taiwan, 2013.

[20] S. De Vecchi, T. Desrues, F. Souche, D. Muñoz, and M. Lemiti, "Laser assisted patterning of hydrogenated amorphous silicon for interdigitated back contact silicon heterojunction solar cell," Proc. SPIE, vol. 8473 pp. 84730R1-84730R10, Oct. 2012.

[21] M. Tucci, L. Serenelli, E. Salza, L. Pirozzi, G. De Cesare, D. Caputo, M. Ceccarelli, P. Martufi, S. De Iuliis, and L. J. Geerligs, "Back enhanced heterostructure with interdigitated contact-BEHIND—solar cell," in Proc. Optoelectron. Microelectron. Mater. Devices, 2008, pp. $242-245$.

[22] B. Shu, U. Das, J. Appel, B. McCandless, S. Hegedus, and R. Birkmire, "Alternative approaches for low temperature front surface passivation of interdigitated back contact silicon heterojunction solar cell," in Proc. 35th IEEE Photovoltaic Spec. Conf., 2010, pp. 3223-3228. 
[23] B. J. O'Sullivan, T. Bearda, Y. Qiu, J. Robbelein, C. Gong, N. E. Posthuma, I. Gordon, and J. Poortmans, "Interdigitated rear contact solar cells with amorphous silicon heterojunction emitter," in Proc. 35th IEEE Photovoltaic Spec. Conf., 2010, pp. 3549-3552.

[24] A. Descoeudres, Z. C. Holman, L. Barraud, S. Morel, S. De Wolf, and C. Ballif, " $>21 \%$ efficient silicon heterojunction solar cells on $n-$ and p-type wafers compared," IEEE J. Photovoltaics, vol. 3, no. 1, pp. 83-89, Jan. 2013.

[25] K. Meyer, C. Schmiga, R. Jesswein, M. Dupke, J. Lossen, M. Hermle, and S. W. Glunz, "All screen-printed industrial n-type Czochralski silicon solar cells with aluminium rear emitter and selective front surface field," in Proc. 35th IEEE Photovoltaic Spec. Conf., 2010, pp. 3531-3535.

[26] Z. R. Chowdhury, K. Cho, and N. P. Kherani, "High-quality surface passivation of silicon using native oxide and silicon nitride layers," Appl. Phys. Lett., vol. 101, no. 2, pp. 021601-1-021601-4, 2012.

[27] Z. R. Chowdhury, D. Stepanov, D. Yeghikyan, and N. P. Kherani, "Excellent low temperature passivation scheme with reduced optical absorption for back amorphous-crystalline silicon heterojunction (BACH) photovoltaic device," in Proc. 37th IEEE Photovoltaic Spec. Conf., 2011, pp. 1026-1028.

[28] J. Ziegler, J. Haschke, T. Käsebier, L. Korte, A. N. Sprafke, and R. B. Wehrspohn, "Influence of black silicon surfaces on the performance of back-contacted back silicon heterojunction solar cells," Opt. Exp., vol. 22, no. S6, pp. A1469-A1476, Sep. 2014.

[29] T. Ohrdes, U. Römer, Y. Larionova, R. Peibst, P. P. Altermatt, and N.-P. Harder, "High fill-factors of back-junction solar cells without front surface field diffusion," in Proc. 27th Eur. Photovoltaic Sol. Energy Conf., Sep. 2012, pp. 5-8.

[30] R. Peibst, U. Römer, Y. Larionova, H. Schulte-Huxel, T. Ohrdes, M. Häberle, B. Lim, D. Stichenoth, T. Wütherich, C. Schöllhorn, J. Graff, and R. Brendel, "Building blocks for back-junction back-contacted cells and modules with ion-implanted poly-Si junctions," in Proc. 40th IEEE Photovoltaic Spec. Conf., 2014, pp. 852-856.

[31] R. Peibst, N.-P. Harder, A. Merkle, T. Neubert, S. Kirstein, J. Schmidt, F. Dross, P. Basore, and R. Brendel, "High-efficiency RISE-IBC solar cells: influence of rear side-passivation on pn-junction meander recombination," in Proc. 28th Eur. Photovoltaic Sol. Energy Conf., 2013, pp. 971-975.

[32] M. Lu, U. Das, S. Bowden, S. Hegedus, and R. Birkmire, "Optimization of interdigitated back contact silicon heterojunction solar cells: Tailoring hetero-interface band structures while maintaining surface passivation," Prog. Photovoltaics Res. Appl., vol. 19, pp. 326-338, 2011.

[33] C. Reichel, F. Granek, M. Hermle, and S. W. Glunz, "Investigation of electrical shading effects in back-contacted back-junction silicon solar cells using the two-dimensional charge collection probability and the reciprocity theorem," J. Appl. Phys., vol. 109, no. 2, pp. 024507-1-024507-12, 2011.

[34] M. Hermle, F. Granek, O. Schultz-Wittmann, and S. W. Glunz, "Shading effects in back-junction back-contacted silicon solar cells," in Proc. 33rd IEEE Photovoltaic Spec. Conf., 2008, pp. 10-13.

[35] D. Diouf, J. P. Kleider, T. Desrues, and P.-J. Ribeyron, "Study of interdigitated back contact silicon heterojunctions solar cells by two-dimensional numerical simulations," Mater. Sci. Eng. B, vols. 159/160, pp. 291-294, Mar. 2009.

[36] D. Diouf, J. P. Kleider, T. Desrues, and P. J. Ribeyron, “2D simulations of interdigitated back contact heterojunction solar cells based on n-type crystalline silicon," Phys. Status Solidi, vol. 7, nos. 3/4, pp. 1033-1036, Feb. 2010.

[37] B. Demaurex, S. De Wolf, A. Descoeudres, Z. C. Holman, and C. Ballif, "Damage at hydrogenated amorphous/crystalline silicon interfaces by indium tin oxide overlayer sputtering," Appl. Phys. Lett., vol. 101, pp. 171604-1-171604-4, 2012.

[38] A. Tomasi, B. Paviet-Salomon, D. Lachenal, S. Martin De Nicolas, A. Descoeudres, S. Nicolay, S. De Wolf, C. Ballif, "Lithography-free interdigitated back-contacted silicon heterojunction solar cells with efficiency > 21\%," in Proc. 40th IEEE Photovoltaic Spec. Conf., 2014, pp. 3644-3648.

[39] R. A. Sinton and A. Cuevas, "A quasi-steady-state open-circuit voltage method for solar cell characterization," in Proc. 16th Eur. Photovoltaic Sol. Energy Conf., 2000, pp. 1-4.

[40] S. C. Baker-Finch and K. R. McIntosh, "A freeware program for precise optical analysis of the front-surface of a solar cell," in Proc. 35th IEEE Photovoltaic Spec. Conf., 2010, pp. 2184-2187.

[41] J. Wong, S. Duttagupta, R. Stangl, B. Hoex, and A. G. Aberle, "A systematic loss analysis method for rear-passivated silicon solar cells," IEEE J. Photovoltaics, vol. 5, no. 2, pp. 619-626, Mar. 2015.
[42] F. J. Wilkinson, A. J. D. Farmer, and J. Geist, "Near ultraviolet quantum yield of silicon.," J. Appl. Phys., vol. 54, no. 1983, pp. 1172-1174, 1983.

[43] S. Kolodinski, J. H. Werner, T. Wittchen, and H. J. Queisser, "Quantum efficiencies exceeding unity due to impact ionization in silicon solar cells," Appl. Phys. Lett., vol. 63, no. 1993, pp. 2405-2407, 1993.

[44] K. R. McIntosh, E. T. Frankhn, D. Wang, N. E. Grant, and I. Lighthouse, "Quantifying the optical losses in back-contact solar cells," in Proc. 40th IEEE Photovoltaic Spec. Conf., 2014, pp. 115-123.

[45] A. Richter, M. Hermle, and S. W. Glunz, "Reassessment of the limiting efficiency for crystalline silicon solar cells," IEEE J. Photovoltaics, vol. 3, no. 4, pp. 1184-1191, Oct. 2013.

[46] R. Woehl, M. Hörteis, and S. W. Glunz, "Determination of the effective optical width of screen printed and aerosol printed and plated fingers," in Proc. 23rd Eur. Photovoltaic Sol. Energy Conf., 2008, pp. $1377-1382$.

[47] A. Faes, M. Despeisse, J. Levrat, J. Champliaud, N. Badel, M. Kiaee, T. Söderström, Y. Yao, R. Grischke, M. Gragert, J. Ufheil, P. Papet, B. Strahm, G. Cattaneo, J. Cattin, Y. Baumgartner, A. Hessler-Wyser, and C. Ballif, "SmartWire solar cell interconnection technology," in Proc. 29th Eur. Photovoltaic Sol. Energy Conf., 2014, pp. 2555-2561.

[48] K. R. McIntosh, N. C. Shaw, and J. E. Cotter, "Light trapping in SunPower's A-300 solar cells," in Proc. 19h Eur. Photovoltaic Sol. Energy Conf., Jun. 2004, pp. 844-847.

[49] L. Barraud, Z. C. Holman, N. Badel, P. Reiss, A. Descoeudres, C. Battaglia, S. De Wolf, and C. Ballif, "Hydrogen-doped indium oxide/indium tin oxide bilayers for high-efficiency silicon heterojunction solar cells," Sol. Energy Mater. Sol. Cells, vol. 115, pp. 151-156, 2013.

[50] S. Kluska, F. Granek, M. Rüdiger, M. Hermle, and S. W. Glunz, "Modeling and optimization study of industrial n-type high-efficiency back-contact back-junction silicon solar cells," Sol. Energy Mater. Sol. Cells, vol. 94, no. 3, pp. 568-577, Mar. 2010.

[51] Z. C. Holman, M. Filipic, A. Descoeudres, S. De Wolf, F. Smole, M. Topic, and C. Ballif, "Infrared light management in high-efficiency silicon heterojunction and rear-passivated solar cells," J. Appl. Phys., vol. 113, no. 1, pp. 013107-1-013107-13, 2013.

[52] Z. C. Holman, M. Filipič, B. Lipovšek, S. De Wolf, F. Smole, M. Topič, and C. Ballif, "Parasitic absorption in the rear reflector of a silicon solar cell: Simulation and measurement of the sub-bandgap reflectance for common dielectric/metal reflectors," Sol. Energy Mater. Sol. Cells, vol. 120, pp. 426-430, Jan. 2014.

[53] M. Hermle, F. Granek, O. Schultz, and S. W. Glunz, "Analyzing the effects of front-surface fields on back-junction silicon solar cells using the charge-collection probability and the reciprocity theorem," J. Appl. Phys., vol. 103, no. 5, pp. 054507-1-054507-7, 2008.

[54] F. Granek, M. Hermle, and S. W. Glunz, "Analysis of the current linearity at low illumination of high-efficiency back-junction back-contact silicon solar cells," Phys. Status Solidi-Rapid Res. Lett., vol. 2, no. 4, pp. 151$153,2008$.

[55] D. Diouf, J. P. Kleider, T. Desrues, and P.-J. Ribeyron, "Effects of the front surface field in n-type interdigitated back contact silicon heterojunctions solar cells," Energy Procedia, vol. 2, pp. 59-64, Aug. 2010.

[56] R. Hezel and R. Schörner, "Plasma Si nitride-A promising dielectric to achieve high-quality silicon MIS/IL solar cells," J. Appl. Phys., vol. 52, no. 1981, pp. 3076-3079, 1981.

[57] R. Hezel, "Low-temperature surface passivation of silicon for solar cells," J. Electrochem. Soc., vol. 136, no. 2, pp. 518-523, 1989.

[58] F. Einsele, W. Beyer, and U. Rau, "Analysis of sub-stoichiometric hydrogenated silicon oxide films for surface passivation of crystalline silicon solar cells," J. Appl. Phys., vol. 112, no. 5, pp. 054905-1-054905-8, 2012.

[59] K. Ding, U. Aeberhard, F. Finger, and U. Rau, "Silicon heterojunction solar cell with amorphous silicon oxide buffer and microcrystalline silicon oxide contact layers," Phys. Status Solidi-Rapid Res. Lett., vol. 6, no. 5, pp. 193-195, May 2012.

[60] M. Otto, M. Kroll, T. Kasebier, R. Salzer, A. Tunnermann, and R. B. Wehrspohn, "Extremely low surface recombination velocities in black silicon passivated by atomic layer deposition," Appl. Phys. Lett., vol. 100, no. 19, pp. 191603-1-191603-4, 2012.

[61] P. Repo, A. Haarahiltunen, L. Sainiemi, M. Yli-Koski, H. Talvitie, M. C. Schubert, and H. Savin, "Effective passivation of black silicon surfaces by atomic layer deposition," IEEE J. Photovoltaics, vol. 3, no. 1, pp. 90-94, Jan. 2013.

[62] Y. Wan, K. R. McIntosh, A. F. Thomson, A. Cuevas, and S. Member, "Low surface recombination velocity by low-absorption silicon nitride on c-Si," IEEE J. Photovoltaics, vol. 3, no. 1, pp. 554-559, Jan. 2013.

[63] M.-L. Kuo, D. J. Poxson, Y. S. Kim, F. W. Mont, J. K. Kim, E. F. Schubert, and S.-Y. Lin, "Realization of a near-perfect antireflection coating for 
silicon solar energy utilization.," Opt. Lett., vol. 33, no. 21, pp. 25272529, Nov. 2008.

[64] S. Lien, D. Wuu, W. Yeh, and J. Liu, "Tri-layer antireflection coatings $\left(\mathrm{SiO}_{2} / \mathrm{SiO}_{2}-\mathrm{TiO}_{2} / \mathrm{TiO}_{2}\right)$ for silicon solar cells using a sol-gel technique," Sol. Energy Mater. Sol. Cells, vol. 90, no. 16, pp. 2710-2719, Oct. 2006.

[65] Z. P. Ling, T. Mueller, A. G. Aberle, and R. Stangl, "Development of a conductive distributed Bragg reflector for heterojunction solar cells using n-doped microcrystalline silicon and aluminum-doped zinc oxide films," IEEE J. Photovoltaics, vol. 4, no. 6, pp. 1320-1325, Nov. 2014.

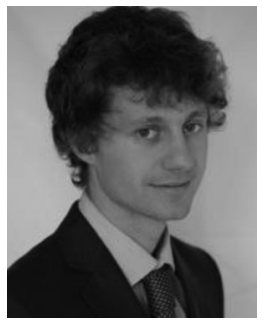

Bertrand Paviet-Salomon was born in Lyon, France, in 1986. He received the M.Sc. degree in 2009 and the Engineer Diploma degree in theoretical and applied optics from the Institut d'Optique, Paris, France. From 2009 to 2012, he was pursuing the Ph.D. degree with the French National Institute for Solar Energy, Le-Bourget-du-Lac, France, working on laser processes for crystalline silicon solar cells. He received the Ph.D. degree in electronics and photonics from the University of Strasbourg, Strasbourg, France, in 2012.

From 2012 to 2014, he was a Postdoctoral Researcher with the Photovoltaics and Thin-Film Electronics Laboratory, École Polytechnique Fédérale de Lausanne, Neuchâtel, Switzerland, working on high-efficiency back-contacted silicon heterojunction solar cells. In 2014, he joined the PV-Center, Centre Suisse d'Électronique et de Microtechnique, Neuchâtel, Switzerland. His research interests include the development of high-efficiency crystalline silicon solar cells.

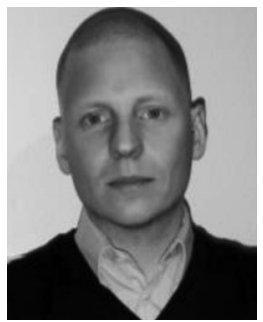

Andrea Tomasi received the Master's degree in physics from the University of Bologna, Bologna, Italy, in 2007, with a thesis on the electrical characterization of nc-Si:H thin films for applications in photovoltaics. Since 2012, he has been working toward the Ph.D. degree on the development of innovative high-efficiency silicon heterojunction solar cell architectures with the Photovoltaics and Thin-Film Electronics Laboratory, École Polytechnique Fédérale de Lausanne, Neuchâtel, Switzerland.

From 2007 to 2011, he was with Xgroup, Padua, Italy, where he was in charge of the ramp-up of several production lines of multicrystalline silicon solar cells and of the technological development of the solar cell production process.

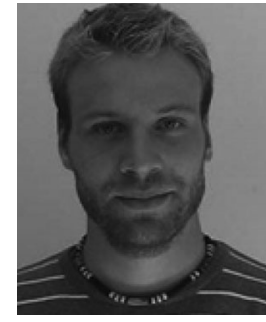

Loris Barraud was born in Le Locle, Switzerland, in 1985. He received the Diplome d'Ingénieur HES degree in microtechnology from the École d'ingénieur du Locle, Neuchâtel, Switzerland, in 2009.

In 2009, he joined the Photovoltaics and Thin Film Electronics Laboratory, École Polytechnique Fédérale de Lausanne, Neuchâtel, as a Scientific Collaborator. In 2013, he joined the PV-Center, Centre Suisse d'Électronique et de Microtechnique, Neuchâtel. His research interests include thin-film deposition for solar cells.

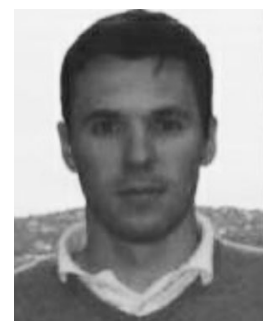

Sylvain Nicolay received the degree in physics engineering from École Polytechnique, Université $\mathrm{Li}$ bre de Bruxelles, Brussels, Belgium, in 2003 and the $\mathrm{Ph} . \mathrm{D}$. degree in photonics from the École Polytechnique Fédérale de Lausanne, Neuchâtel, Switzerland, in 2008, for work on the development of "III-N heterostructures for intersubband transitions."

He then joined the Photovoltaics and ThinFilm Electronics Laboratory, École Polytechnique Fédérale de Lausanne, in 2008, leading the research team working on transparent conductive oxide for photovoltaics applications. Since 2013, he has been in charge of the coating section with the PV-Center, Centre Suisse d'Électronique et de Microtechnique, Neuchâtel.

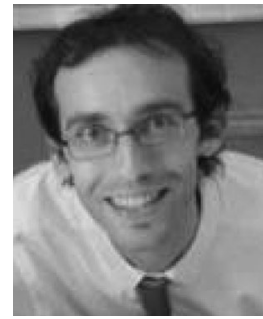

Matthieu Despeisse received the Degree in electrical engineering from INSA, Lyon, France, in 2002 and the Ph.D. degree from CERN, Geneva, Switzerland, in 2006, working on amorphous silicon sensors deposited directly on the readout electronics.

He then worked until 2008 with the European Organization for Particle Physics (CERN). His research focused on novel Silicon radiation sensors (3D, SiPM, a-Si:H), advanced microelectronics, and technology transfer. He then joined the Photovoltaics and Thin-Film Electronics Laboratory, École Polytechnique Fédérale de Lausanne, Neuchâtel, Switzerland, in 2009, leading the research team working on thin-film silicon photovoltaics technology. Since 2013, he has been leading the research activities on crystalline silicon photovoltaics with the PV-Center, Centre Suisse d'Électronique et de Microtechnique, Neuchâtel, Switzerland, with special focus on silicon heterojunction technology, passivating contacts, and metallization.

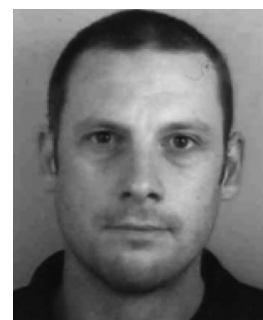

Stefaan De Wolf received the Ph.D. degree from the Catholic University of Leuven, Leuven, Belgium, while he was with IMEC, Heverlee, Belgium, developing crystalline silicon solar cells.

From 2005 to 2008, he was with the National Institute of Advanced Industrial Science and Technology, Tsukuba, Japan, focusing on silicon heterojunction devices. In 2008, he joined the Photovoltaics and Thin-Film Electronics Laboratory, École Polytechnique Fédérale de Lausanne, Neuchâtel, Switzerland, as a Team Leader for its activities on high-efficiency

solar cells

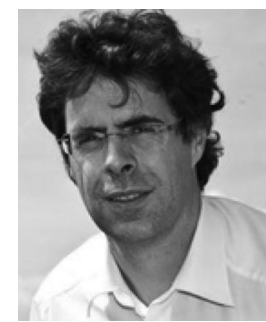

Christophe Ballif received the Graduate's degree in physics and the Ph.D. degree from the École Polytechnique Fédérale de Lausanne (EPFL), Lausanne, Switzerland, in 1994 and 1998, respectively, focusing on novel photovoltaic materials.

He was a Postdoctoral Researcher with National Renewable Energy Laboratory, Golden, CO, USA. $\mathrm{He}$ then was with the Fraunhofer ISE, Freiburg, Germany, where he was involved in crystalline silicon photovoltaics (monocrystalline and multicrystalline) until 2003. He then joined the EMPA, Thun, Switzerland, before becoming a Full Professor and Chair with the Institute of Microengineering, University of Neuchâtel, Neuchâtel, Switzerland, in 2004. In 2009 , the Institute was transferred to EPFL. He is the Director of the Photovoltaics and Thin-Film Electronics Laboratory, Institute of Microengineering, as well as of the PV-Center, Centre Suisse d'Électronique et de Microtechnique, which is dedicated to industrial research and technology transfer. Lausanne, working on the development of silicon heterojunction solar cells. In 2013, he joined the PV-Center, Centre Suisse d'Électronique et de Microtechnique, Neuchâtel. His current research interests include thin-film deposition with plasma-enhanced chemical vapor deposition and plasma diagnostics for the development of high-efficiency silicon heterojunction solar cells 